\title{
Front Matter: Volume 8250
}

, "Front Matter: Volume 8250," Proc. SPIE 8250, Reliability, Packaging, Testing, and Characterization of MEMS/MOEMS and Nanodevices XI, 825001 (16 March 2012); doi: 10.1117/12.928121

SPIE. Event: SPIE MOEMS-MEMS, 2012, San Francisco, California, United States 


\title{
PROCEEDINGS OF SPIE
}

\section{Reliability, Packaging, Testing, and Characterization of MEMS/MOEMS and Nanodevices XI}

\author{
Sonia M. García-Blanco \\ Rajeshuni Ramesham \\ Editors \\ 23-24 January 2012 \\ San Francisco, California, United States \\ Sponsored by \\ SPIE \\ Cosponsored by \\ Dyoptyka (Ireland) \\ VUZIX Corporation (United States) \\ Cooperating Organization \\ Fraunhofer-Institut für Zuverlässigkeit und Mikrointegration (Germany) \\ Published by \\ SPIE
}

Volume 8250 
The papers included in this volume were part of the technical conference cited on the cover and title page. Papers were selected and subject to review by the editors and conference program committee. Some conference presentations may not be available for publication. The papers published in these proceedings reflect the work and thoughts of the authors and are published herein as submitted. The publisher is not responsible for the validity of the information or for any outcomes resulting from reliance thereon.

Please use the following format to cite material from this book:

Author(s), "Title of Paper," in Reliability, Packaging, Testing, and Characterization of MEMS/MOEMS and Nanodevices XI, edited by Sonia M. García-Blanco, Rajeshuni Ramesham, Proceedings of SPIE Vol. 8250 (SPIE, Bellingham, WA, 2012) Article CID Number.

ISSN 0277-786X

ISBN 9780819488930

Published by

SPIE

P.O. Box 10, Bellingham, Washington 98227-0010 USA

Telephone +1 3606763290 (Pacific Time) · Fax +1 3606471445

SPIE.org

Copyright (C) 2012, Society of Photo-Optical Instrumentation Engineers

Copying of material in this book for internal or personal use, or for the internal or personal use of specific clients, beyond the fair use provisions granted by the U.S. Copyright Law is authorized by SPIE subject to payment of copying fees. The Transactional Reporting Service base fee for this volume is $\$ 18.00$ per article (or portion thereof), which should be paid directly to the Copyright Clearance Center (CCC), 222 Rosewood Drive, Danvers, MA 01923. Payment may also be made electronically through CCC Online at copyright.com. Other copying for republication, resale, advertising or promotion, or any form of systematic or multiple reproduction of any material in this book is prohibited except with permission in writing from the publisher. The CCC fee code is 0277-786X/12/\$18.00.

Printed in the United States of America.

Publication of record for individual papers is online in the SPIE Digital Library.

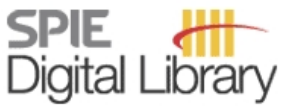

SPIEDigitalLibrary.org

Paper Numbering: Proceedings of SPIE follow an e-First publication model, with papers published first online and then in print and on CD-ROM. Papers are published as they are submitted and meet publication criteria. A unique, consistent, permanent citation identifier (CID) number is assigned to each article at the time of the first publication. Utilization of CIDs allows articles to be fully citable as soon as they are published online, and connects the same identifier to all online, print, and electronic versions of the publication. SPIE uses a six-digit CID article numbering system in which:

- The first four digits correspond to the SPIE volume number.

- The last two digits indicate publication order within the volume using a Base 36 numbering system employing both numerals and letters. These two-number sets start with $00,01,02,03,04$, $05,06,07,08,09,0 A, 0 B \ldots 0 Z$, followed by 10-1Z, 20-2Z, etc.

The CID number appears on each page of the manuscript. The complete citation is used on the first page, and an abbreviated version on subsequent pages. Numbers in the index correspond to the last two digits of the six-digit CID number. 


\section{Contents}

$\checkmark \quad$ Conference Committee

vii $\quad$ Powering the wireless world with MEMS (Plenary Paper) [8248-102]

S. B. Schaevitz, Lilliputian Systems, Inc. (United States)

xxiii New optical, acoustic, and electrical diagnostics for the developing world (Plenary Paper) [8251-103]

S. L. Neale, C. Witte, Y. Bourquin, C. Kremer, A. Menachery, Y. Zhang, R. Wilson, J. Reboud, J. M. Cooper, Univ. of Glasgow (United Kingdom)

\section{SESSION 1 RELIABILITY AND PACKAGING}

825002 Assembly and interconnect formation in MEMS/MOEMS application (Invited Paper) [8250-01]

H. Oppermann, Fraunhofer-Institut für Zuverlässigkeit und Mikrointegration (Germany)

825003 Effects of dry plasma releasing process parameters and induced in-plane stress on MEMS devices yield (Invited Paper) [8250-02]

P. M. Nieva, J. R. Godin, R. C. Norris, A. Najafi Sohi, T. Leung, Univ. of Waterloo (Canada)

825004 Evaluation of surface control and durability CNT and ITO coated PET transparent electrode under different dry conditions [8250-03]

J.-M. Park, Gyeongsang National Univ. (Korea, Republic of) and The Univ. of Utah (United States); D.-J. Kwon, Z.-J. Wang, G.-Y. Gu, Gyeongsang National Univ. (Korea, Republic of); L. DeVries, The Univ. of Utah (United States)

825005 Usage induced changes to surface topography and material properties in polysilicon MEMS electrothermal structures [8250-04]

S. Oak, G. Ramachandran, T. Dallas, Texas Tech Univ. (United States)

825006 Planar refractive microlens arrays with high fill-factor fabricated by polymer replication technique [8250-05]

M. Nam, S. S. Yang, K.-K. Lee, Ajou Univ. (Korea, Republic of)

\section{SESSION 2 MEMS TESTING I}

825007 Axial phase measurements of light interacting with microstructures [8250-06]

M.-S. Kim, T. Scharf, H. P. Herzig, Ecole Polytechnique Fédérale de Lausanne (Switzerland)

$825008 \quad$ Nondestructive static and dynamic MEMS characterization using supercontinuum scanning white light interferometry [8250-07]

V. Heikkinen, K. Hanhijärvi, J. Aaltonen, Univ. of Helsinki (Finland); K. Grigoras, Aalto Univ.

(Finland); I. Kassamakov, Univ. of Helsinki (Finland); S. Franssila, Aalto Univ. (Finland);

E. Haeggström, Univ. of Helsinki (Finland) 
8250 0A Reliability of high I/O high density CCGA interconnect electronic packages under extreme thermal environments [8250-09]

R. Ramesham, Jet Propulsion Lab. (United States)

8250 OB Characterization of flourocarbon SAM coated MEMS tribogauge [8250-10]

A. Vijayasai, G. Ramachandran, G. Sivakumar, C. Anderson, R. Gale, T. Dallas, Texas Tech Univ. (United States)

8250 OC Characterization of a nanocoating using a MEMS tribogauge [8250-11]

A. Vijayasai, G. Ramachandran, G. Sivakumar, C. Anderson, R. Gale, T. Dallas, Texas Tech Univ. (United States)

\section{SESSION 4 SPECIAL SESSION: HOT INDUSTRIAL TOPICS IN MEMS}

$8250 \mathrm{OH}$ The unsettled world of leak rate physics: 1 atm large-volume considerations do not apply to MEMS packages: a practitioner's perspective [8250-20]

R. C. Kullberg, Vacuum Energy, Inc. (United States); A. Jonath, Jonath Associates (United

States); R. K. Lowry, Electronic Materials Characterization (United States)

\section{SESSION 5 MEMS FOR SPACE: JOINT SESSION WITH CONFERENCE 8252}

8250 ol MEMS technology for miniaturized space systems: needs, status, and perspectives (Invited Paper) [8250-16]

E. Gill, J. Guo, Technische Univ. Delft (Netherlands)

$8250 \mathrm{0J}$ MOEMS devices designed and tested for astronomical instrumentation in space (Invited Paper) [8250-17]

F. Zamkotsian, Lab. d'Astrophysique de Marseille, CNRS (France); W. Noell, Ecole

Polytechnique Fédérale de Lausanne (Switzerland)

8250 OK Performance prediction and characterization of highly insulated microbolometers for space applications [8250-18]

Z. Xu, L. Ngo Phong, Canadian Space Agency (Canada); T. D. Pope, INO (Canada)

\section{POSTER SESSION}

$8250 \mathrm{OL} \quad$ Enhanced terahertz transmission by surface plasmon resonance [8250-19]

Y. Wen, J. Yang, X. Yu, Peking Univ. (China); Y. Zhao, X. Liu, L. Dong, Beijing Institute of Technology (China)

Author Index 


\section{Conference Committee}

Symposium Chair

Harald Schenk, Fraunhofer Institute for Photonic Microsystems

(Germany)

Symposium Cochair

David L. Dickensheets, Montana State University (United States)

Conference Chairs

Sonia M. García-Blanco, Universiteit Twente (Netherlands)

Rajeshuni Ramesham, Jet Propulsion Laboratory (United States)

Program Committee

Paul Bierden, Boston Micromachines Corporation (United States)

Christopher K. Harrison, Schlumberger-Doll Research Center (United States)

Allyson Hartzell, Lilliputian Systems Inc. (United States)

Albert K. Henning, Nanolnk, Inc. (United States)

Maurice S. Karpman, Draper Laboratory (United States)

Kee-Keun Lee, Ajou University (Korea, Republic of)

Richard C. Kullberg, Vacuum Energy, Inc. (United States)

Herbert R. Shea, Ecole Polytechnique Fédérale de Lausanne (Switzerland)

Tolga Tekin, Technische Universität Berlin (Germany)

Yanzhu Zhao, Medtronic, Inc. (United States) 
Downloaded From: https://www.spiedigitallibrary.org/conference-proceedings-of-spie on 26 Apr 2023

Terms of Use: https://www.spiedigitallibrary.org/terms-of-use 